\title{
BUSINESS'S CORPORATE SOCIAL RESPONSIBILITY AT THE POST-SOVIET AREA: FEATURES OF ASSESSING THE EFFECTIVENESS OF AN INDUSTRY ORGANIZATION'S SOCIAL SPHERE
}

\author{
Alena Malei \\ Polotsk State University, Belarus \\ Katsiaryna Afanasyeva \\ Polotsk State University, Belarus
}

\begin{abstract}
The global trend of developing the institute of social responsibility of businesses leads to the need to train specialists with new professional competences in the practical application of the concept of corporate social responsibility, taking into account the peculiarities of the social sphere of industrial organizations in the post-Soviet countries. The purpose of this study is to develop a methodical toolkit to assess the effectiveness of the management of the social sphere of industrial enterprises within the framework of the concept of corporate social responsibility. Methods of theoretical and empirical research, methodological techniques and approaches used in the analysis of the activities of enterprises by Western experts, as well as their modifications, allowing to take into account the specifics of the economic situation of the post-Soviet countries, were used as methodological tools.

The article discusses the methodological features of assessing the effectiveness of an industrial organizations' social sphere within the framework of applying the CSR concept at the postSoviet space. The authors propose a system for evaluating the effectiveness and forecasting the activity of the social sphere of industrial organizations in four key areas: social, economic, organizational, and technological efficiency, which meet the main targets of the activities of such entities. The authors have developed a new system of balanced indicators that allows to assess the efficiency of the functioning of cultural and recreational facilities that are on the balance sheet of industrial organizations, focusing on the interests of various parties: both external and internal stakeholders, based on the optimal ratio of economic benefit and social result. The new CSR procedure related to the integration of social reporting with the system of key performance indicators will allow monitoring the effectiveness of the industrial organizations' social sphere by aggregated indicators within the framework of management by goals and is a powerful tool for strategic planning of their activities.
\end{abstract}

Keywords: balanced scorecard, corporate social responsibility, evaluation of the effectiveness of cultural institutions social report. 
Malei \& Afanasyeva, 2021. Business's Corporate Social Responsibility at the Post-Soviet Area: Features of Assessing the Effectiveness of an Industry Organization's Social Sphere

\section{Introduction}

In the context of the dynamic transformation of global socio-economic processes, the modern system of higher education is focused on updating educational programs according to the latest global tendencies. The concept of corporate social responsibility (CSR) of business developed abroad is only gaining momentum in the post-Soviet countries and has its own implementation features, which are currently poorly studied and not taken into account in training economic specialists, which makes it difficult to spread the concept to the territory of the former USSR countries and reduces the effectiveness of its realization. In this regard, it becomes relevant to study the specifics of the practical application of the corporate social responsibility concept in the post-Soviet space organizations and to use new knowledge in the educational process while preparing economic specialists to make their professional competencies meet modern realities.

Traditionally, the methodology and practice of determining business efficiency has been established with the emphasis on assessing the economic efficiency of an enterprise and social factors being seen as secondary, acting as additional conditions or even limitations. However, for the social sector of industrial enterprises, the task of increasing profits is not the main goal and, accordingly, cannot be the only criterion of efficiency. With regard to the social sphere of an industrial enterprise, within the framework of achieving the sustainable business development goals, the current target can be defined as "fulfilling statutory tasks with optimal costs". Accordingly, both financial and social performance indicators should be taken into account when building a common strategy for the company's development within the CSR. In these conditions, the management of enterprises is tasked with determining the dependence of the economic indicators of an enterprise on the work of the social sphere and developing a system of indicators that assess the effectiveness of managing the social sphere of industrial enterprises, which determine the relevance of this study.

\section{Body of the Article}

Initially, the concept of "social sphere of an enterprise" was formed in the middle of the 20th century in the process of socialization of economic relations. The development of the social sphere of industrial enterprises was largely due to the experience of the USSR, where numerous infrastructure facilities were created for the labor collectives of enterprises, designed to meet the needs of workers in services and ensure the development of the socialist way of life. 
In highly developed foreign countries (Japan, Germany, USA, Great Britain, France, etc.) with a market economy, the social sphere developed within the framework of the concept of "welfare state" and "prosperity society." By the end of the 20th century, the social content had changed in the direction of providing a number of services paid for from the company's funds, and the feasibility of keeping social facilities on the company's balance sheet had been confirmed by the relevant economic calculations. Gradually, the owner of the enterprise comes to understand that the social sphere is not a "burden" affecting the increase in the cost of the goods produced, but a complex and necessary element, allowing to increase the motivation of the employee to work, to ensure the attraction of highly qualified specialists, to increase the efficiency of production and productivity. As a result, by the beginning of the third millennium, the concept of "social sphere" had developed into a complex set of socio-economic relations between the enterprise and the employee, which provides services to the diverse needs of the employee of the enterprise (material, spiritual, social, etc.) through the creation of social services by the facilities of the social sphere in the internal environment of the enterprise or the acquisition of these services by the enterprise from thirdparty organizations, creating the most favorable conditions for labor activity and ultimately affecting the increase in the economic performance of the enterprise (Shvaiba, 2017).

In most countries of the world, the development of the social sphere of enterprises is under the influence of the developing institution of social responsibility of business, which directs business to solve the most pressing problems of society at the global and regional level by making any production decisions while considering social, economic and environmental consequences.

In recent years, the social responsibility of business has been implemented within the framework of the UN documents "Global Compact", "Millennium Development Goals", "UN Norms on the Responsibilities of Transnational Corporations and Other Business Enterprises with regard to Human Rights". Today the Global Compact brings together more than 10,500 businesses and about 3000 non-profit organizations from 160 countries (Global Compact Network Belarus, 2020).

The social responsibility of business in the post-Soviet space is only gaining momentum and has its own peculiarities. Industrial enterprises of post-Soviet countries (Republic of Belarus, Russian Federation, Kazakhstan, Uzbekistan, Azerbaijan, etc.) have preserved social facilities created during the administrative-command system. Unlike Western models, due to the presence of elements of the command system inherited from Soviet times, the role of the state in the formation and development of social responsibility of enterprises in the post-Soviet countries still has a decisive role. Therefore, to ensure sustainable social development, one of the most effective models of interaction between the 
Malei \& Afanasyeva, 2021. Business's Corporate Social Responsibility at the Post-Soviet Area: Features of Assessing the Effectiveness of an Industry Organization's Social Sphere

enterprise and the state in the social sphere is the position of "cooperation and dialogue", in which the state and the enterprise jointly determine the priorities of social policy, as well as areas where an economic entity can bear a "social burden" taking into account the interests of stakeholders.

Given the existence of large state-owned enterprises with a vast social sphere of the old type, it is necessary to more accurately characterize the concept of "social responsibility" for the countries of the former USSR:

- $\quad$ it is necessary to talk not only about activities beyond the legally regulated minimum, but also about the need to comply with the requirements stipulated in the laws;

- $\quad$ at the same time, it is necessary to present appropriate wording that allows enterprises to have clear and measurable benchmarks;

- all actions of enterprises must be in accordance with the expectations of the staff and generally accepted standards of ethics (Shvaiba, 2017).

Thus, regardless of the Western or post-Soviet development model of the CSR concept, social responsibility should become a modern style of business activity, which can have a meaningful impact on the management decisionmaking process, taking into account the interests of all stakeholders as well as the philosophy within which enterprises will create and develop a modern social sphere (economically justified, meeting the needs of the team and the company strategy).

Theoretical and methodological approaches to define the concept of corporate social responsibility (CSR) with the identification of principles and tools, as well as the directions of its implementation are presented in the works of the classics of the CSR theory M. Friedman (Freeman, 1994) and T. Levitt (Levitt, 1958). Various aspects of the socially responsible behavior of companies were considered in the works of G. Bowen (Bowen, 1953), who proposed the theory of social security of his own staff, and K. Davis (Davis, 1960), who first studied the problems of social responsibility in a management context. J. McGuire (McGuire, 1963) made a significant contribution to the development of the concept of social orientation of business, pointing out not only the economic and legal obligations of business, but also its responsibility to society. The need to harmonize CSR with the theory of corporate sustainability was proposed by L. Nancy and F. Kotler (Kotler \& Nancy, 2007), R. Steuer, M. Langer, A. Conrad and A. Martinuzzi (Steurer, Langer, Konrad, \& Martinuzzi, 2005), A. Caroll (Caroll, 1999), J. Post, L.E. Preston (Post, Preston, \& Sachs, 2002) made a special contribution to the development of the theory of ethical business responsibility to stakeholders.

Among the authors who study in detail the issues of socially responsible behavior in the countries of the post-Soviet space, the direction of transformation of social sphere facilities, it is necessary to highlight V.F. Baynev (Bainev, 2008), 
A.V. Rutskiy, I. S. Polonik (Rutskiy, 2012), D. Shvaiba (Shvaiba, 2017), etc. At the same time, the problem of assessing the effectiveness of the social sphere of industrial enterprises, both in domestic and foreign literature, is insufficiently covered. Theoretical developments in this area are reduced to a minor adaptation of the methods of foreign countries without taking into account the specifics of the functioning of the social sphere facilities of industrial organizations in the post-Soviet space, there is no guidance on their practical implementation.

To date, there is no generally accepted system of indicators for assessing the effectiveness of the social sphere of an industrial enterprise, due to a number of circumstances:

1) the difficulty of reasonably choosing the universal threshold values of indicators of the "normal state" of the social sphere for all enterprises, as their values may be subjective;

2) not all indicators of the effectiveness of the functioning of the social sphere can be quantified;

3) the state of the information base for objective and comprehensive monitoring of the effectiveness of the social sphere is largely determined not by the needs of the enterprise, but by its capabilities;

4) the calculation of indicators considered in isolation from each other does not allow to draw conclusions with a high degree of certainty about the real situation, as deviation from the norm of one or even several indicators may not always characterize the overall situation in the enterprise.

In world practice, the following methods are used to assess the effectiveness of the activities of social institutions:

- various systems of unbalanced indicators used in the framework of the method of results-based management of the social sphere;

- Balanced Scorecard (BSC);

- a management assessment model for state or municipal-funded organizations - Common Assessment Framework (CAF).

- a model for assessing the effectiveness of budget institutions based on integral indicators;

- $\quad$ an economic-symbolic approach to assessing the effectiveness of the social sphere.

The world's most popular tool for measuring a company's performance in strategic planning is the Balanced Scorecard (BSC), which reflects the most important aspects of the business. Based on empirical research, the creators of the system, Kaplan and Norton (early 90s of the XX century), proved that successful companies in their goal systems take into account at least four perspectives: Finance, Customers, Processes and Potential (Kaplan, \& Norton, 2003). Based on 
Malei \& Afanasyeva, 2021. Business's Corporate Social Responsibility at the Post-Soviet Area: Features of Assessing the Effectiveness of an Industry Organization's Social Sphere

the balanced scorecard concept, modern scientists identify four groups of indicators to evaluate the performance of an industrial organization, which are linked to each other by a logical cause-and-effect chain of goals and are in a certain hierarchical subordination to each other:

- traditional financial indicators;

- $\quad$ the company's external environment and customer relations;

- $\quad$ the company's internal processes (business processes);

- the company's ability to learn and grow (Krasnova, 2012).

Balanced Scorecard's logic assumes that the metrics that a company includes in such a system depend on what the company sets for itself, hence the basis of the Balanced Scorecard system is not indicators, but goals. Although the concept of the BSC is universal, the system of balanced indicators itself must adapt to specific conditions and be developed for a particular country or industry, taking into account certain business conditions and internal management practices. Consequently, the BSC should be developed separately for any business entity and area of economic activity.

Unlike the management of the economic and production indicators of an enterprise, when the efficiency of operation is assessed to a greater extent by production indicators (profitability of enterprises, labor productivity, etc.), the efficiency of the social sphere of industrial organizations,inour opinion, should be assessed by social performance taking into account other types of effect. In the works of I. Vasilkova (Vasil'kova, 2008), T.T. Fisyuk (Fisyuk \& Zakharova, 2017), S.A. Mukhamedieva (Mukhamediyeva, 2011) the effectiveness of a social facility of industrial organizations is based on the segregation of the following types of effects in the economy:

- The economic effect involves the increase in productivity and the reduction of labor intensity, material consumption and cost, the growth of profit and profitability.

- $\quad$ The resource effect, in turn, reflects the release of resources in the enterprise: material, labor and financial.

- The technical effect is the result of the emergence of new equipment and technology, discoveries, inventions and rationalization proposals, know-how and other innovations.

- The social effect points to the increase in the material and cultural standard of living of citizens, better satisfaction of their needs for goods and services, the improvement of working conditions and safety, the decrease in the share of heavy manual labor, etc.

Having studied the system of calculating the efficiency of industrial companies, determined by the Balanced Scorecard, and the types of efficiency 
generated by social facilities, we have developed a system of assessments that determine the effectiveness of the social sphere of industrial organizations.

\section{Table 1 Comparison of Performance Indicators of an Industrial Organization and a Social Sphere of Industrial Organizations Based on the BSC (created by the authors)}

\begin{tabular}{|l|l|}
\hline \multicolumn{1}{|c|}{$\begin{array}{c}\text { BSC, classic groups of } \\
\text { performance indicators }\end{array}$} & $\begin{array}{l}\text { The proposed system of assessments of the effectiveness of } \\
\text { the social sphere facilities of industrial organizations }\end{array}$ \\
\hline $\begin{array}{l}\text { Traditional financial } \\
\text { indicators }\end{array}$ & $\begin{array}{l}\text { Assessment of cost-effectiveness: } \\
\text { - economic efficiency indicators. }\end{array}$ \\
\hline $\begin{array}{l}\text { The company's external } \\
\text { environment and customer } \\
\text { relations }\end{array}$ & $\begin{array}{l}\text { Assessment of social effectiveness: } \\
\text { - social performance indicators }\end{array}$ \\
\hline $\begin{array}{l}\text { Internal processes of the } \\
\text { company (Business } \\
\text { Processes) }\end{array}$ & $\begin{array}{l}\text { Assessment of organizational performance: } \\
\text { - organizational performance indicators }\end{array}$ \\
\hline $\begin{array}{l}\text { The company's ability to } \\
\text { learn and grow }\end{array}$ & $\begin{array}{l}\text { Assessment of technological efficiency: } \\
\text { - labor efficiency indicators } \\
\text { - indicators of the efficiency of using the material and } \\
\text { technical base }\end{array}$ \\
\hline
\end{tabular}

The theory of steakholders, formulated by R. Freeman (Freeman, 1994), proves the need to take into account the interests of all those who are in one way or another affected by the activities of the enterprise. The social sphere of an industrial organization should be considered from three points: as a part of an industrial organization that performs common tasks with it; as a subdivision of an industrial organization that performs specific functions; as a business entity with its own goals and results.

In this regard, users of information about the effective use of the social sphere of industrial organizations should be divided into 3 groups and the interests of each when selecting indicators to assess performance should be taken into account (Figure 1).

A study of the degree of interest in social reporting by various user groups conducted by the Association of Managers showed that the most significant target audience, which is based on information about social programs and projects, is the staff of companies (Korsokova \& Litovchenko, 2003). Thus, the system of indicators reflecting the effectiveness of the social sphere of an industrial organization, firstly, should take into account the interests of internal and external groups of users of the social sphere of an industrial organization, but to a greater extent reflect the interests of employees of an industrial organization, as a group that takes the most important and significant decisions for the development of the social sphere; secondly, must be balanced, i.e. interconnected by financial and non-financial indicators. 
Malei \& Afanasyeva, 2021. Business's Corporate Social Responsibility at the Post-Soviet Area: Features of Assessing the Effectiveness of an Industry Organization's Social Sphere

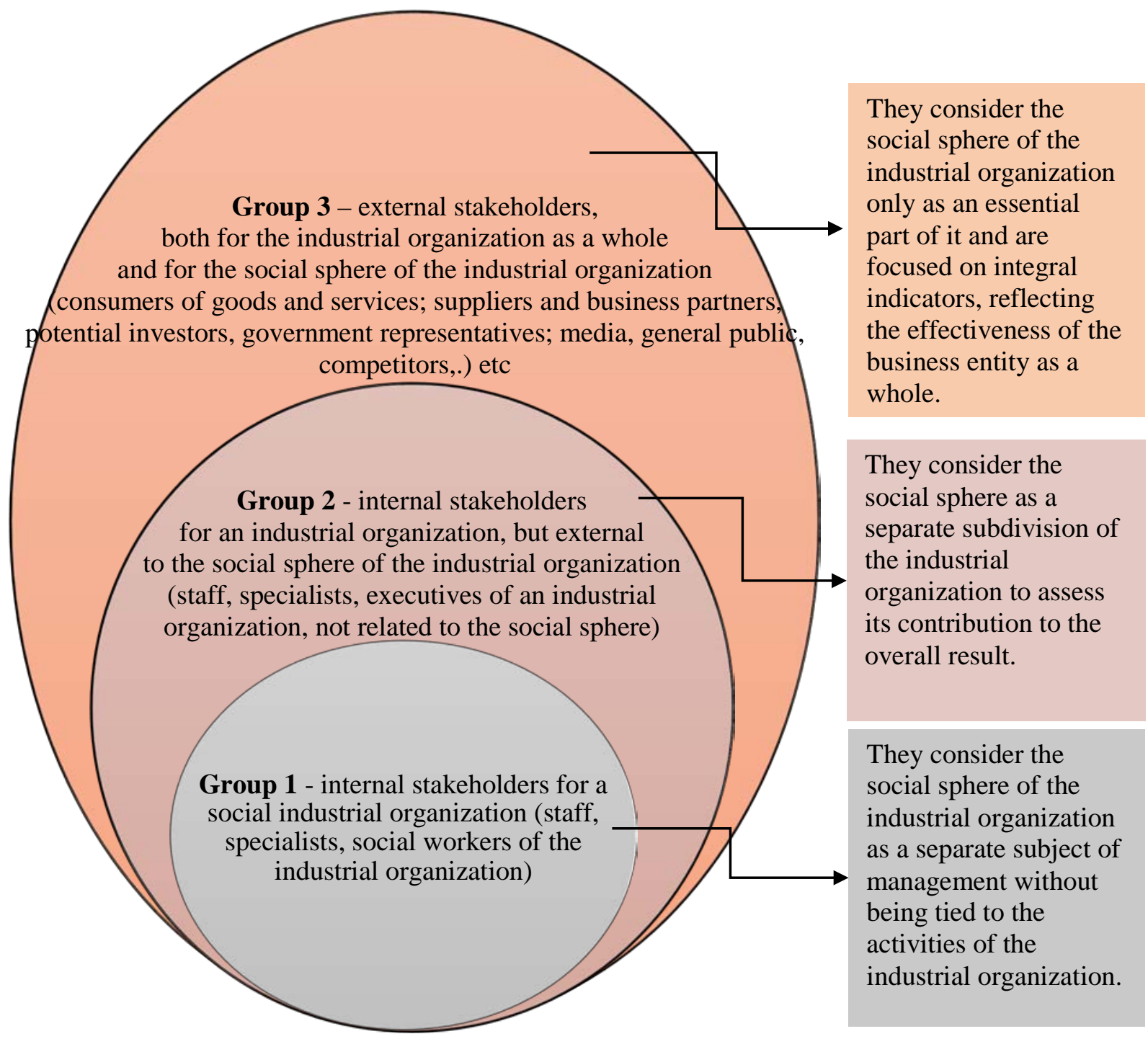

Figure 1 Stakeholder Groups for a Social Sphere of Industrial Organization (created by the authors)

A significant part of the total volume of the social sphere of industrial enterprises are cultural and recreational facilities. In the Republic of Belarus, for example, $4.4 \%$ of enterprises have "houses of culture" and $2.4 \%$ maintain "palaces of culture" (which are club institutions, centers of cultural and educational work); $6.8 \%$ of enterprises finance the maintenance of clubs; $2.4 \%$ have libraries (Shvaiba, 2017). Therefore, within the framework of this article we will develop a system of balanced indicators to assess the effectiveness of the social sphere of industrial organizations on the example of their cultural and recreational facilities.

From the point of view of its economic interpretation, it is advisable to consider the sphere of culture in two aspects: as an activity aimed at creating a unique creative product that can act as a commodity (paintings, music, 
performances, classes in clubs, etc.); and as an activity that contributes to the formation and development of new qualities of human capital (creativity, talent, qualifications), the use of which can bring additional income in the process of creative activity. Obtaining tangible and intangible results determines the specifics of the functioning of organizations in the field of culture and leads to difficulties in assessing the effectiveness of their activities. Cultural efficiency refers to accelerating achievements in the development and augmentation of cultural values, their dissemination and communication to the population, and establishing a connection between the results obtained and the costs of communication to determine the degree of justification for expenditure.

In accordance with table 1, we will take a look at the social, economic, organizational and technological effectiveness of cultural and recreational facilities within industrial organizations grouped by different categories of users.

Let's look at the first group of indicators that assess the social efficiency of cultural organizations. Social efficiency is the alignment of the results of the cultural institution to the basic social needs and goals of society, as well as to the interests of the individual. Assessment of social efficiency is an indicator showing the ability of the institution to achieve its social and socially significant goals. In our opinion, the criteria for the efficiency of cultural organizations should be tied directly to the extent to which their statutory functions are performed.

These functions are:

- communicative - carried out through events that allow to share experience in various fields of activity (forums, festivals, seminars, exhibitions, master classes);

- $\quad$ educational - implemented through educational, leisure programs, such as schools for young actors, vocal development, choreographic art, club formations;

- $\quad$ cultural and educational - provided by the activities of creative amateur groups (deserved, folk, exemplary);

- $\quad$ leisure - carried out through the participation of employees and citizens in various creative, entertainment, leisure programs and projects (Fisyuk \& Zakharova, 2017).

The activities of cultural organizations can be recognized as socially effective with the fullest coverage of all types of activities provided for by the charter and obtaining the most significant results in the form of an increase in attendance at events, acquisition of new customers, creation of creative products, and receiving awards at competitions. To assess the social efficiency of cultural institutions within industrial organizations, we propose to calculate and reflect in the corporate social report the following indicators, detailed by groups of stakeholders, presented in Table 2. 
Malei \& Afanasyeva, 2021. Business's Corporate Social Responsibility at the Post-Soviet Area: Features of Assessing the Effectiveness of an Industry Organization's Social Sphere

Table 2 Proposed Indicators for Assessing Social Efficiency of Cultural Institutions within Industrial Organizations (created by the authors)

\begin{tabular}{|c|c|c|}
\hline Indicator & Calculation procedure & Note \\
\hline \multicolumn{3}{|c|}{ Group 1 of stakeholders } \\
\hline $\begin{array}{l}\text { The total number of } \\
\text { cultural and recreational } \\
\text { activities held in the } \\
\text { cultural institution in the } \\
\text { reporting year }\end{array}$ & - & $\begin{array}{l}\text { Characterizes the effectiveness of } \\
\text { the activities of a cultural } \\
\text { institution in organizing events }\end{array}$ \\
\hline $\begin{array}{l}\text { The share of socially } \\
\text { significant cultural and } \\
\text { recreational activities }\end{array}$ & $\begin{array}{l}\text { Number of socially significant } \\
\text { cultural and recreational activities } \\
\text { in the cultural institution / The } \\
\text { total number of cultural and } \\
\text { recreational activities held in the } \\
\text { cultural institution in the } \\
\text { reporting year. }\end{array}$ & $\begin{array}{l}\text { Shows the share of socially } \\
\text { significant cultural and } \\
\text { recreational activities in the total } \\
\text { number of cultural and } \\
\text { recreational activities held by the } \\
\text { cultural institution }\end{array}$ \\
\hline $\begin{array}{l}\text { The attendance ratio (by } \\
\text { types of social projects) }\end{array}$ & $\begin{array}{l}\text { The number of people attending } \\
\text { social projects of cultural } \\
\text { institutions (clubs, seminars, } \\
\text { theatrical productions, etc.) / The } \\
\text { maximum number of people } \\
\text { present, based on the established } \\
\text { standarts }\end{array}$ & $\begin{array}{l}\text { Reflects the level of attendance at } \\
\text { cultural institutions. Participants' } \\
\text { standards are calculated taking } \\
\text { into account the capacity of the } \\
\text { premises. }\end{array}$ \\
\hline $\begin{array}{l}\text { The average number of } \\
\text { people involved in clubs } \\
\text { of a cultural institution } \\
\text { for the reporting period }\end{array}$ & $\begin{array}{l}\text { The sum of the average monthly } \\
\text { number of people involved in the } \\
\text { clubs of a cultural institution for } \\
\text { all months of the reporting year / } \\
(12 * \text { Average monthly number of } \\
\text { clubs operating in the reporting } \\
\text { period) }\end{array}$ & $\begin{array}{l}\text { Reflects the average fullness of } \\
\text { cultural institution clubs }\end{array}$ \\
\hline $\begin{array}{l}\text { The new customer } \\
\text { acquisition rate }\end{array}$ & $\begin{array}{l}\text { The number of "new" customers } \\
\text { during the reporting period / } \\
\text { Number of customers during the } \\
\text { reporting period }\end{array}$ & $\begin{array}{l}\text { Reflects the effectiveness of } \\
\text { attracting new customers and } \\
\text { "luring away" customers of } \\
\text { competitors. }\end{array}$ \\
\hline \begin{tabular}{|l|} 
The number of creative \\
amateur groups with \\
honorary titles \\
(deserved, folk, \\
exemplary) \\
\end{tabular} & - & $\begin{array}{l}\text { Reflects the level of } \\
\text { professionalism of the leaders of } \\
\text { creative amateur groups of the } \\
\text { cultural institution }\end{array}$ \\
\hline $\begin{array}{l}\text { The share of } \\
\text { competitive victories }\end{array}$ & $\begin{array}{l}\text { The number of victories in } \\
\text { competitions / Total number of } \\
\text { participations in competitions } \\
\text { during the reporting period }\end{array}$ & $\begin{array}{l}\text { Characterizes the quality of } \\
\text { training and participation of } \\
\text { teams in competitions and } \\
\text { professionalism of creative } \\
\text { amateur groups leaders }\end{array}$ \\
\hline
\end{tabular}




\begin{tabular}{|c|c|c|}
\hline \multicolumn{3}{|c|}{ Group 2 of stakeholders } \\
\hline The diversity ratio & $\begin{array}{l}\text { The number of activities carried } \\
\text { out in the institution of culture / } \\
\text { The total number of activities, } \\
\text { according to the list of activities } \\
\text { for an institution of culture }\end{array}$ & $\begin{array}{l}\text { Shows the share of services } \\
\text { carried out in the total number of } \\
\text { creative activities provided by } \\
\text { cultural institutions }\end{array}$ \\
\hline $\begin{array}{l}\text { The ratio of industrial } \\
\text { organization workers' } \\
\text { interest in the services } \\
\text { of cultural institution } \\
\text { (by types of activity) }\end{array}$ & $\begin{array}{l}\text { The number of employees of an } \\
\text { industrial organization who } \\
\text { received services (by types of } \\
\text { activity) in the cultural institution } \\
\text { during the reporting period / The } \\
\text { average number of employees of } \\
\text { an industrial organization during } \\
\text { the reporting period }\end{array}$ & $\begin{array}{l}\text { It allows you to assess the share } \\
\text { of industrial organization } \\
\text { employees' involvement in } \\
\text { obtaining services in the cultural } \\
\text { institution of an industrial } \\
\text { organization }\end{array}$ \\
\hline $\begin{array}{l}\text { The percentage of } \\
\text { implementation of the } \\
\text { plan on the social } \\
\text { indicators brought by the } \\
\text { industrial organization } \\
\text { to the cultural institution } \\
\text { (the number of cultural } \\
\text { and recreational } \\
\text { activities, the attendance } \\
\text { rate of events, etc.) }\end{array}$ & Actual Value / Plan value * $100 \%$ & $\begin{array}{l}\text { It shows the ability of the team to } \\
\text { perform the tasks set by the } \\
\text { industrial organization for } \\
\text { sociocultural activities. }\end{array}$ \\
\hline \multicolumn{3}{|c|}{ Group 3 of stakeholders } \\
\hline $\begin{array}{l}\text { The consumer } \\
\text { satisfaction rate }\end{array}$ & Numerical score & $\begin{array}{l}\text { Reflects an objective assessment } \\
\text { of the relationship of cultural } \\
\text { organizations with customers } \\
\text { based on questionnaires }\end{array}$ \\
\hline $\begin{array}{l}\text { The communicative } \\
\text { activity ratio }\end{array}$ & $\begin{array}{l}\text { The number of events held by the } \\
\text { cultural institution / The total } \\
\text { number of events of national } \\
\text { importance held by all cultural } \\
\text { institutions of the region }\end{array}$ & $\begin{array}{l}\text { Characterizes the involvement of } \\
\text { the cultural institution in the } \\
\text { events of the republican nature }\end{array}$ \\
\hline $\begin{array}{l}\text { The educational activity } \\
\text { ratio }\end{array}$ & $\begin{array}{l}\text { The number of types of } \\
\text { educational programs } \\
\text { implemented in the institution of } \\
\text { culture / The total number of types } \\
\text { of educational programs provided } \\
\text { for cultural institutions in the } \\
\text { country }\end{array}$ & $\begin{array}{l}\text { Reflects the degree of } \\
\text { implementation of educational } \\
\text { programs in the institution of } \\
\text { culture }\end{array}$ \\
\hline $\begin{array}{l}\text { The cultural and } \\
\text { educational activity ratio }\end{array}$ & $\begin{array}{l}\text { The number of creative amateur } \\
\text { groups with honorary titles } \\
\text { (deserved, folk, exemplary) / The } \\
\text { total number of creative amateur } \\
\text { groups with honorary titles }\end{array}$ & \begin{tabular}{|l|} 
Shows the level of \\
professionalism of the leaders of \\
creative amateur groups of \\
cultural institutions in the region
\end{tabular} \\
\hline
\end{tabular}


Malei \& Afanasyeva, 2021. Business's Corporate Social Responsibility at the Post-Soviet Area: Features of Assessing the Effectiveness of an Industry Organization's Social Sphere

\begin{tabular}{|c|c|c|}
\hline & $\begin{array}{l}\text { (deserved, folk, exemplary) in the } \\
\text { region }\end{array}$ & \\
\hline The leisure activity ratio & $\begin{array}{l}\text { The number of residents of the } \\
\text { city (region), participating in } \\
\text { cultural and recreational activities } \\
\text { conducted by cultural institutions } \\
\text { and in the work of amateur } \\
\text { associations in the reporting } \\
\text { period / The average number of } \\
\text { residents of the city (region) in } \\
\text { the reporting period }\end{array}$ & $\begin{array}{l}\text { Allows to assess the interest of } \\
\text { the residents of the city (region) } \\
\text { in the services of the cultural } \\
\text { institution }\end{array}$ \\
\hline
\end{tabular}

The generalized indicators of social efficiency of cultural institutions, which are studied by the third group of stakeholders (external stakeholders), determine how well (or not very well) cultural institutions implement educational, leisure, communication projects, and improve the quality of cultural and educational work in the city (region). Such indicators of a cultural institution allow stakeholders to assess the complexity of performing the functions characteristic of the statutory activities of a cultural institution and to compare various cultural institutions of a city (region) with each other. Much attention should be paid to the consumer satisfaction indicator, which will reflect an objective assessment of the relationship of cultural organizations of industrial organizations with customers. In order to determine it, it is necessary to place information about a cultural institution on a specialized platform for assessing the quality of services of such organizations and conduct a survey of consumers with a final score (for example, 1 - very dissatisfied, 5 - very satisfied). An independent assessment system is necessary to form the responsibility of organizations providing social services, and to increase the degree of customer confidence in the cultural institution, subsequently increasing sales.

Next, we will consider the following group of indicators characterizing the economic efficiency of a cultural object as part of an industrial organization, including indicators that are both related to the external environment of cultural institutions of industrial organizations and reflecting the internal processes of cultural institutions of industrial organizations.

Since cultural institutions are often organizations with a mixed form of financing (funds of large companies on the balance sheet of which they are located, and funds from their own commercial activities), it is necessary to analyze the effectiveness of both the investments of the industrial organization and the effectiveness of the work of the cultural institution itself. As a motivational goal for assessing the degree of self-financing of their own projects in cultural institutions, which are taken into account in the balance sheet of industrial organizations, one can set the required level of the ratio of types of 
financing, for example, strive for the ratio of one earned ruble to one ruble of funds invested in the maintenance of a cultural institution.

As indicators of economic efficiency, reflecting the internal processes of the enterprise, we also propose to use in cultural institutions such an indicator as the share of costs per 1 man-hour, in other words, the calculation of "per capita" financing. So, for the education sector, such an indicator is calculated on the basis of the plan of the educational program and the number of students mastering it. The amount of man-hours for a cultural institution can be calculated on the basis of the schedule of classes for concert ensembles and self-sustaining ensembles and the number of people involved in these ensembles, and is the basis for determining the amount of financial support for all standard costs required, for example, when drawing up an estimate of costs for the upcoming reporting year.

To assess the economic efficiency of a cultural institution, managers of an industrial organization calculate the coefficients for the implementation of the plan according to the indicators brought by the industrial organization and set the limit figures for the possible (permissible) deviation from the plan, which, by the decision of the founder, is usually $5-10 \%$. Within the framework of these indicators, the plan is considered fulfilled and its financing - reasonable.

The proposed indicators for assessing economic efficiency and the procedure for their calculation are presented in Table 3.

Table 3 Proposed Indicators for Assessing the Economic Efficiency of a Cultural Institution as Part of an Industrial Organization (created by the authors)

\begin{tabular}{|c|c|c|}
\hline Indicator & Calculation procedure & Note \\
\hline \multicolumn{3}{|c|}{ Group 1 of stakeholders } \\
\hline $\begin{array}{l}\text { Growth rate of the } \\
\text { service sales }\end{array}$ & $\begin{array}{l}\text { The revenue amounts for the } \\
\text { reporting period, adjusted for the } \\
\text { inflation index / The revenue } \\
\text { amounts for the previous reporting } \\
\text { period }\end{array}$ & $\begin{array}{l}\text { Characterizes the level of } \\
\text { development of the client } \\
\text { orientation of the cultural institution }\end{array}$ \\
\hline $\begin{array}{l}\text { The ratio of costs per } \\
\text { man-hour }\end{array}$ & $\begin{array}{l}\text { The ratio of the actual costs of } \\
\text { maintaining a cultural institution } \\
\text { for the reporting period / (The } \\
\text { number of clients engaged in } \\
\text { clubs, visitors to events, concerts, } \\
\text { performances, etc. * the time they } \\
\text { spent within the walls of the } \\
\text { institution (according to the } \\
\text { schedule of classes, the time of } \\
\text { cultural and entertainment } \\
\text { events))*100\% }\end{array}$ & $\begin{array}{l}\text { Determines the share of costs per } 1 \\
\text { client, attributable to } 1 \text { hour of } \\
\text { classes in circles (attendance of } \\
\text { events). } \\
\text { The indicator can be calculated } \\
\text { separately for each department of } \\
\text { the palace of culture, which provides } \\
\text { revenue (the department of cultural } \\
\text { and mass work and the department } \\
\text { for the organization of artistic } \\
\text { activities), if there is a separate } \\
\text { accounting of the costs incurred in } \\
\text { these departments }\end{array}$ \\
\hline
\end{tabular}


Malei \& Afanasyeva, 2021. Business's Corporate Social Responsibility at the Post-Soviet Area: Features of Assessing the Effectiveness of an Industry Organization's Social Sphere

\begin{tabular}{|c|c|c|}
\hline $\begin{array}{l}\text { Productivity of one } \\
\text { cultural institution } \\
\text { employee }\end{array}$ & $\begin{array}{l}\text { The revenue for the reporting } \\
\text { period / The average number of } \\
\text { employees of a cultural institution }\end{array}$ & $\begin{array}{l}\text { Determines the amount of revenue } \\
\text { that each employee of the cultural } \\
\text { institution provides. The increase in } \\
\text { this indicator is not achieved by } \\
\text { reducing the number of staff, but by } \\
\text { increasing the productivity of their } \\
\text { work by investing in their skills. }\end{array}$ \\
\hline Return on fixed assets & $\begin{array}{l}\text { The amount of revenue of the } \\
\text { cultural institution for the } \\
\text { reporting period / The average } \\
\text { annual value of fixed assets of a } \\
\text { cultural institution }\end{array}$ & $\begin{array}{l}\text { Shows how effectively the fixed } \\
\text { assets are used in cultural } \\
\text { institutions }\end{array}$ \\
\hline Material efficiency & $\begin{array}{l}\text { The amount of revenue of the } \\
\text { cultural institution for the } \\
\text { reporting period / Material costs of } \\
\text { a cultural institution }\end{array}$ & $\begin{array}{l}\text { Shows how effectively material } \\
\text { resources are used in cultural } \\
\text { institutions }\end{array}$ \\
\hline \multicolumn{3}{|c|}{ Group 2 of stakeholders } \\
\hline $\begin{array}{l}\text { Payback of the cost of } \\
\text { maintaining the } \\
\text { cultural institution by } \\
\text { an industrial } \\
\text { organization }\end{array}$ & $\begin{array}{l}\text { The amount of profit from the } \\
\text { provision of services of a cultural } \\
\text { institution for the reporting period } \\
/ \text { The amount of expenses for } \\
\text { maintenance and operation for the } \\
\text { reporting period }\end{array}$ & $\begin{array}{l}\text { Allows you to evaluate the } \\
\text { effectiveness of the activities of a } \\
\text { cultural institution, taking into } \\
\text { account the funds earned } \\
\text { independently by the cultural } \\
\text { institution for its maintenance }\end{array}$ \\
\hline $\begin{array}{l}\text { The ratio of social } \\
\text { expenditures of an } \\
\text { industrial } \\
\text { organization }\end{array}$ & $\begin{array}{l}\text { The amount of expenses spent on } \\
\text { the maintenance of the cultural } \\
\text { institution / General expenses of } \\
\text { the industrial organization }\end{array}$ & $\begin{array}{l}\text { Shows the share of social } \\
\text { expenditures in the total } \\
\text { expenditures of the industrial } \\
\text { organization during the reporting } \\
\text { period }\end{array}$ \\
\hline $\begin{array}{|lr|}\text { The ratio of } & \text { cultural } \\
\text { expenditure r } & \text { per } \\
\text { worker of } & \text { an } \\
\text { industrial } & \\
\text { organization } & \end{array}$ & $\begin{array}{l}\text { Total expenses of cultural } \\
\text { institution / Average number of } \\
\text { employees in an industrial } \\
\text { organization }\end{array}$ & $\begin{array}{l}\text { Determines the amount of costs on } \\
\text { average per one employee of the } \\
\text { company for the reporting year, } \\
\text { which makes it possible to justify } \\
\text { these costs for the maintenance of a } \\
\text { cultural institution in front of the } \\
\text { company's management in terms of } \\
\text { the main task of the functioning of } \\
\text { this structural unit - organizing } \\
\text { leisure activities for employees, } \\
\text { pensioners and their families }\end{array}$ \\
\hline $\begin{array}{l}\text { The percentage of the } \\
\text { implementation of the } \\
\text { plan brought to the } \\
\text { cultural institution by } \\
\text { the industrial } \\
\text { organization } \\
\text { (revenue, profit, costs, } \\
\text { etc.) }\end{array}$ & Actual Value / Plan value * $100 \%$ & $\begin{array}{l}\text { Shows the ability of the team to } \\
\text { perform the tasks set by the } \\
\text { industrial organization. }\end{array}$ \\
\hline
\end{tabular}




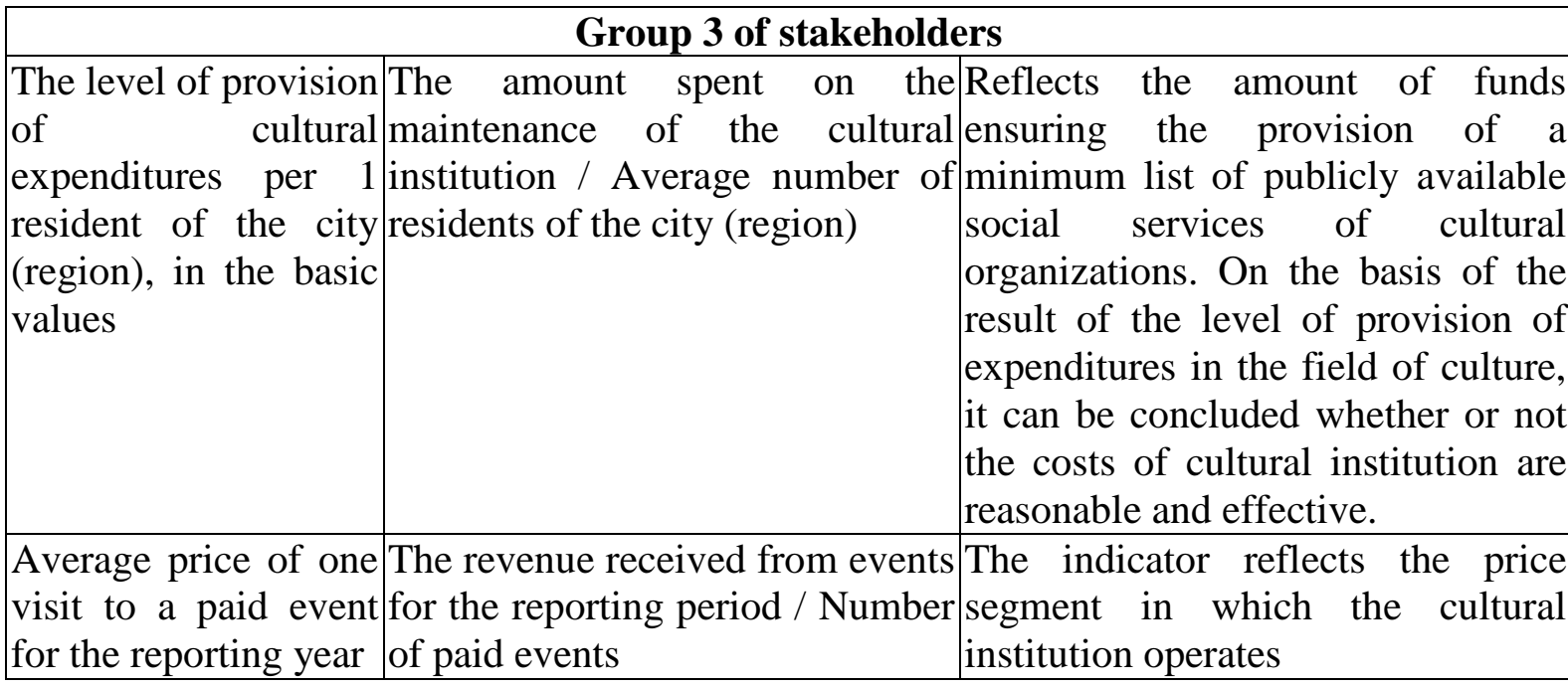

Next, we will consider the indicators designed to assess the organizational efficiency of the social sphere subject. This group of indicators makes it possible to identify the main processes that cultural organizations need to improve in order to strengthen competitive advantages and ensure the loyalty of stakeholders. The indicators in this group are based on the processes that make a major contribution to achieving targeted financial results and customer satisfaction.

Organizational efficiency studies should identify: whether the cultural institution is working according to modern personnel technologies; whether it has a clear structure - approved job descriptions, a clear form of accounting and monitoring of activities; does a computerized accounting of employees, clients; application of new innovative technologies for the convenience of customers.

Let's summarize the proposed indicators of organizational performance evaluation and the procedure for calculating them in Table 4.

Table 4 Proposed Indicators for Assessing the Organizational Efficiency of a Cultural Institution (created by the authors)

\begin{tabular}{|l|l|l|}
\hline \multicolumn{1}{|c|}{ Indicator } & Calculation procedure & \multicolumn{1}{|c|}{ Group 1 of stakeholders } \\
\hline \multicolumn{2}{|c|}{} & $\begin{array}{l}\text { Allows you to determine if a cultural } \\
\text { institution uses the latest technologies to } \\
\text { optimize internal business processes }\end{array}$ \\
\hline $\begin{array}{l}\text { The use of an automated } \\
\text { accounting system }\end{array}$ & The fact of availability \\
\hline $\begin{array}{l}\text { The use of an automated } \\
\text { personnel accounting } \\
\text { system }\end{array}$ & The fact of availability \\
\hline $\begin{array}{l}\text { The level of internal } \\
\text { control of the cultural testing the method of } \\
\text { institution }\end{array}$ & $\begin{array}{l}\text { Characterizes the quality of the system of } \\
\text { control system }\end{array}$ \\
\hline $\begin{array}{l}\text { Indicator of the novelty } \\
\text { of the development of percentage of } \\
\text { the cultural institution }\end{array}$ & renewal of annual plans & Characterizes the degree of timely renewal \\
\hline
\end{tabular}


Malei \& Afanasyeva, 2021. Business's Corporate Social Responsibility at the Post-Soviet Area: Features of Assessing the Effectiveness of an Industry Organization's Social Sphere

\begin{tabular}{|c|c|c|}
\hline & $\begin{array}{l}\text { for the development of a } \\
\text { cultural institution }\end{array}$ & $\begin{array}{l}\text { institution, the inclusion of modern new } \\
\text { methods of work }\end{array}$ \\
\hline \multicolumn{3}{|c|}{ Group 2 of stakeholders } \\
\hline $\begin{array}{l}\text { Percentage } \\
\text { implementation of the } \\
\text { plan brought by the } \\
\text { industrial organization } \\
\text { to the establishment of } \\
\text { culture indicators on } \\
\text { intra-organization } \\
\text { activities }\end{array}$ & $\begin{array}{l}\text { Actual Value / Plan } \\
\text { value } * 100 \%\end{array}$ & $\begin{array}{l}\text { Shows the ability of the team to fulfill the } \\
\text { tasks set by the industrial organization for } \\
\text { the cultural institution. Overfulfillment of } \\
\text { the plan will indicate deficiencies in } \\
\text { planning. }\end{array}$ \\
\hline \multicolumn{3}{|c|}{ Group 3 of stakeholders } \\
\hline $\begin{array}{|lrr|}\text { Application } & \text { of } & \text { an } \\
\text { automated } & \text { billing } \\
\text { system in } & \text { the } \\
\text { implementation } & & \text { of } \\
\text { services } & & \end{array}$ & The fact of availability & \multirow{2}{*}{$\begin{array}{l}\text { Reveals the main processes that cultural } \\
\text { organizations need to improve to strengthen } \\
\text { competitive advantage and to ensure the } \\
\text { loyalty of external stakeholders }\end{array}$} \\
\hline $\begin{array}{|ll|}\text { Application } & \text { of the } \\
\text { electronic } & \text { ticketing } \\
\text { system } & \end{array}$ & The fact of availability & \\
\hline $\begin{array}{l}\text { The share of digitized } \\
\text { results of the activities } \\
\text { of a cultural institution }\end{array}$ & $\begin{array}{l}\text { The number of digitized } \\
\text { results of the activities } \\
\text { of a cultural institution / } \\
\text { The total number of } \\
\text { results of the activities } \\
\text { of a cultural institution }\end{array}$ & $\begin{array}{l}\text { Determines how much the latest technology } \\
\text { is used to create an accessible environment } \\
\text { for customers }\end{array}$ \\
\hline
\end{tabular}

The last set of indicators, which we will look at, is designed to assess the technological efficiency of the subject of the social sphere. Technological efficiency refers to an assessment of an organization's ability to make efficient use of resources in the process of transforming them into the result of activities, including non-profit activities. This group of indicators is a synergistic result of two main factors: labor resources and material and technical support of the cultural institution.

When analyzing the efficiency of the use of labor resources, it is necessary to assess the level of education and professional skill of personnel; staff turnover, the proportion of certified employees and continuing professional development on an ongoing basis; compare the level of wages and labor productivity of social workers with the average indicators of an industrial organization, and standards for the country as a whole. The state of the material and technical base is assessed by analyzing the use of the areas of a cultural institution buildings, the effectiveness of capital investments of an industrial organization, the technical condition of the fixed assets of a cultural institution. 
Let's summarize the proposed indicators for assessing technological efficiency and the procedure for their calculation in Table 5.

Table 5 The Proposed Indicators for Assessing Technological

Efficiency of a Cultural Institution (created by the authors)

\begin{tabular}{|c|c|c|}
\hline Indicator & Calculation procedure & Note \\
\hline 1 & 2 & 3 \\
\hline \multicolumn{3}{|c|}{ The indicators of the use of labor force } \\
\hline \multicolumn{3}{|c|}{ Group 1 of stakeholders } \\
\hline $\begin{array}{l}\text { The average number } \\
\text { of employees of a } \\
\text { cultural institution } \\
\text { during the reporting } \\
\text { period }\end{array}$ & $\begin{array}{l}\text { The sum of the average monthly } \\
\text { number of employees for all } \\
\text { months of the reporting year / } 12\end{array}$ & $\begin{array}{l}\text { Reflects the average number of } \\
\text { employees of a cultural institution } \\
\text { during the reporting period }\end{array}$ \\
\hline $\begin{array}{l}\text { The ratio of creative } \\
\text { staff of a cultural } \\
\text { institution }\end{array}$ & $\begin{array}{l}\text { The average number of creative } \\
\text { staff for the reporting period / } \\
\text { The average number of } \\
\text { employees of ta cultural } \\
\text { institution during the reporting } \\
\text { period }\end{array}$ & $\begin{array}{l}\text { Reflects the number of people } \\
\text { engaged in creative activities in the } \\
\text { cultural institution during the } \\
\text { reporting period }\end{array}$ \\
\hline Staff turnover rate & $\begin{array}{l}\text { The number of dismissed } \\
\text { employees of an institution who } \\
\text { were eliminated during the } \\
\text { reporting period for reasons of } \\
\text { turnover (on their own will, for } \\
\text { absenteeism, for violation of } \\
\text { safety precautions, unauthorized } \\
\text { leaving and other reasons) / The } \\
\text { average number of employees of } \\
\text { a cultural institution during the } \\
\text { reporting period }\end{array}$ & $\begin{array}{l}\text { Shows staff turnover in a cultural } \\
\text { institution }\end{array}$ \\
\hline $\begin{array}{l}\text { The level of } \\
\text { education of } \\
\text { personnel and } \\
\text { professional skills }\end{array}$ & $\begin{array}{l}\text { Number of employees with } \\
\text { higher education / Average } \\
\text { number of employees of a } \\
\text { cultural institution during the } \\
\text { reporting period }\end{array}$ & $\begin{array}{l}\text { Shows the level of professionalism } \\
\text { of cultural institution workers }\end{array}$ \\
\hline $\begin{array}{l}\text { The ratio of personnel } \\
\text { who completed } \\
\text { training, advanced } \\
\text { training (at least once } \\
\text { every } 5 \text { years) } \\
\end{array}$ & $\begin{array}{l}\text { The number of staff trained (at } \\
\text { least once every } 5 \text { years) / The } \\
\text { average number of employees of } \\
\text { a cultural institution during the } \\
\text { reporting period }\end{array}$ & $\begin{array}{l}\text { Shows the level of training of the } \\
\text { creative staff of a cultural institution }\end{array}$ \\
\hline $\begin{array}{l}\text { Percentage of } \\
\text { certified staff }\end{array}$ & $\begin{array}{l}\text { The number of staff certified in } \\
\text { the reporting period of a cultural } \\
\text { institution / The average number } \\
\text { of employees of a cultural } \\
\text { institution }\end{array}$ & $\begin{array}{l}\text { Shows the share of workers } \\
\text { certified in the reporting year of a } \\
\text { cultural institution }\end{array}$ \\
\hline
\end{tabular}


Malei \& Afanasyeva, 2021. Business's Corporate Social Responsibility at the Post-Soviet Area: Features of Assessing the Effectiveness of an Industry Organization's Social Sphere

\begin{tabular}{|c|c|c|}
\hline Incidence rate & $\begin{array}{l}\text { The number of days of absence of } \\
\text { employees on sick leave / } \\
\text { Apparent total working time, in } \\
\text { days }\end{array}$ & $\begin{array}{l}\text { Characterizes the absence of } \\
\text { workers in the workplace due to } \\
\text { illness during the reporting period } \\
\text { in a cultural institution }\end{array}$ \\
\hline \multicolumn{3}{|c|}{ Group 2 of stakeholders } \\
\hline $\begin{array}{l}\text { The ratio of cultural } \\
\text { institution workers in } \\
\text { the total number of } \\
\text { employees of an } \\
\text { industrial } \\
\text { organization }\end{array}$ & \begin{tabular}{|l|} 
The average number of \\
employees of a cultural institution \\
during the reporting period / The \\
average number of employees of \\
an industrial organization
\end{tabular} & $\begin{array}{l}\text { Reflects the proportion of } \\
\text { employees associated with the } \\
\text { functioning of a cultural institution } \\
\text { in the total number of employees of } \\
\text { an industrial organization }\end{array}$ \\
\hline \begin{tabular}{|l|} 
The labor \\
productivity index of \\
one employee of a \\
cultural institution
\end{tabular} & $\begin{array}{l}\text { The average labor productivity } \\
\text { per one employee of a cultural } \\
\text { institution / The average labor } \\
\text { productivity per one employee of } \\
\text { an industrial organization as a } \\
\text { whole }\end{array}$ & $\begin{array}{l}\text { Reflects the efficiency of using the } \\
\text { labor resources of a cultural } \\
\text { institution in comparison with the } \\
\text { efficiency of using labor resources } \\
\text { of an industrial organization }\end{array}$ \\
\hline $\begin{array}{l}\text { The cultural } \\
\text { institution workers' } \\
\text { pay index }\end{array}$ & $\begin{array}{l}\text { The average monthly nominal } \\
\text { accrued wages of employees of } \\
\text { cultural institutions / The average } \\
\text { monthly wages of workers in an } \\
\text { industrial organization }\end{array}$ & $\begin{array}{l}\text { evel of pay for cultural } \\
\text { vorkers compared to } \\
\text { industrial organization }\end{array}$ \\
\hline \multicolumn{3}{|c|}{ Group 3 of stakeholders } \\
\hline $\begin{array}{l}\text { The coefficient of } \\
\text { assessment of work of } \\
\text { employees of a } \\
\text { cultural institution }\end{array}$ & \begin{tabular}{|l} 
The actual amount of work \\
performed by a specialist, hours / \\
The amount of work that must be \\
performed by a specialist \\
according to standard
\end{tabular} & $\begin{array}{l}\text { An indicator that provides an } \\
\text { assessment of the effectiveness of } \\
\text { the work of specialists of a cultural } \\
\text { institution }\end{array}$ \\
\hline $\begin{array}{l}\text { The level of } \\
\text { remuneration of } \\
\text { employees of a } \\
\text { cultural institution } \\
\text { compared to the } \\
\text { national average } \\
\end{array}$ & $\begin{array}{l}\text { The average monthly nominal } \\
\text { accrued wages of employees of } \\
\text { cultural institutions / Average } \\
\text { monthly salary of employees of } \\
\text { cultural institutions in the country }\end{array}$ & $\begin{array}{l}\text { Reflects the level of remuneration of } \\
\text { workers of a cultural institution } \\
\text { compared to workers of cultural } \\
\text { institutions in the country as a whole }\end{array}$ \\
\hline \multicolumn{3}{|c|}{ Indicators of the use of the material and technical base } \\
\hline \multicolumn{3}{|c|}{ Group 1 of stakeholders } \\
\hline $\begin{array}{l}\text { The total area of the } \\
\text { cultural institution } \\
\text { building }\end{array}$ & $\begin{array}{l}\text { According to technical } \\
\text { documentation }\end{array}$ & $\begin{array}{l}\text { Reflects the area of the cultural } \\
\text { institution building }\end{array}$ \\
\hline $\begin{array}{l}\text { The utilization rate of } \\
\text { the area of a cultural } \\
\text { institution }\end{array}$ & $\begin{array}{l}\text { The area used by the cultural } \\
\text { institution to provide services / } \\
\text { The total area of the cultural } \\
\text { institution building }\end{array}$ & $\begin{array}{l}\text { Shows how fully the area of the } \\
\text { cultural institution building is used }\end{array}$ \\
\hline \multicolumn{3}{|c|}{ Group 2 of stakeholders } \\
\hline $\begin{array}{l}\text { The amount of } \\
\text { expenses for the } \\
\text { maintenance and }\end{array}$ & $\begin{array}{l}\text { Expenses for the maintenance and } \\
\text { operation of a cultural institution }\end{array}$ & $\begin{array}{l}\text { Reflects the amount of the } \\
\text { industrial organization's } \\
\text { expenditure on the maintenance and }\end{array}$ \\
\hline
\end{tabular}




\begin{tabular}{|c|c|c|}
\hline $\begin{array}{l}\text { operation of } 1 \mathrm{~m}^{2} \text { of } \\
\text { the area of a cultural } \\
\text { institution building }\end{array}$ & $\begin{array}{l}\text { building / The total area of a } \\
\text { cultural institution building }\end{array}$ & $\begin{array}{l}\text { operation of } 1 \mathrm{~m}^{2} \text { of the area of a } \\
\text { cultural institution building }\end{array}$ \\
\hline $\begin{array}{l}\text { The amount of } \\
\text { revenue per } 1 \mathrm{~m}^{2} \text { of } \\
\text { the used area of a } \\
\text { cultural institution } \\
\text { building }\end{array}$ & $\begin{array}{l}\text { The amount of revenue of a } \\
\text { cultural institution for the } \\
\text { reporting period / The building } \\
\text { area used by a cultural institution } \\
\text { for the provision of services }\end{array}$ & $\begin{array}{l}\text { Shows how effectively the building } \\
\text { is used in a cultural institution }\end{array}$ \\
\hline \begin{tabular}{|l|} 
The efficiency of \\
capital investments in \\
a cultural institution
\end{tabular} & $\begin{array}{l}\text { The increase in income of a } \\
\text { cultural institution due to capital } \\
\text { investments of an industrial } \\
\text { organization / The amount of } \\
\text { investments of an industrial } \\
\text { organization in a r cultural } \\
\text { institution }\end{array}$ & $\begin{array}{l}\text { Reflects the efficiency of capital } \\
\text { investments of an industrial } \\
\text { organization in a cultural institution } \\
\text { due to income growth }\end{array}$ \\
\hline \multicolumn{3}{|c|}{ Group 3 of stakeholders } \\
\hline $\begin{array}{l}\text { The area occupancy } \\
\text { rate per } 1 \mathrm{~m}^{2}\end{array}$ & $\begin{array}{l}\text { The maximum number of people } \\
\text { engaged in clubs at the same time } \\
\text { / Cultural building area used by a } \\
\text { cultural institution to provide } \\
\text { services }\end{array}$ & $\begin{array}{l}\text { Reflects the degree of } \\
\text { of conducting collectiv } \\
\text { clients per } 1 \mathrm{~m}^{2}\end{array}$ \\
\hline $\begin{array}{l}\text { The material and } \\
\text { technical base } \\
\text { depreciation rate }\end{array}$ & $\begin{array}{l}\text { The amount of depreciation } \\
\text { deductions of fixed assets in a } \\
\text { cultural institution / The initial } \\
\text { value of fixed assets in a cultural } \\
\text { institution }\end{array}$ & $\begin{array}{l}\text { Reflects the degree of depreciation } \\
\text { of fixed assets in a cultural } \\
\text { institution. Fixed assets depreciation } \\
\text { rate standard is no more than } 50 \% \text {. }\end{array}$ \\
\hline $\begin{array}{l}\text { The material and } \\
\text { technical base } \\
\text { renewal rate }\end{array}$ & $\begin{array}{l}\text { The cost of fixed assets put into } \\
\text { operation during the reporting } \\
\text { year in a cultural institution / The } \\
\text { cost of fixed assets at the end of } \\
\text { the reporting year in a cultural } \\
\text { institution }\end{array}$ & $\begin{array}{l}\text { Shows the degree of renewal of the } \\
\text { material and technical base in a } \\
\text { cultural institution, the use of new } \\
\text { technology. }\end{array}$ \\
\hline
\end{tabular}

For a general assessment of the effectiveness of the activities of a cultural institution within an industrial organization in the social report, we propose to present a consolidated efficiency index based on the calculation of indices for each type of efficiency: social, economic, organizational, technological. When calculating each of the components of the consolidated efficiency index, first of all, it is necessary to establish the minimum and maximum values of the indicators that are proposed for calculation in tables 2-5, based on the standards and conditions for the activity of a cultural institution within of an industrial organization, with which the actual data will be compared.

The calculation of the consolidated efficiency index can be carried out in three stages. The first stage is to determine the social efficiency index; economic efficiency index; organizational efficiency index; the technological efficiency 
Malei \& Afanasyeva, 2021. Business's Corporate Social Responsibility at the Post-Soviet Area: Features of Assessing the Effectiveness of an Industry Organization's Social Sphere

index using the "index by element" according to formula 1 , if the improvement in the dynamics of the analyzed indicator is expressed in its growth and formula 2, if the improvement of the analyzed indicator is expressed in its decrease:

$$
\begin{aligned}
& I_{i}=\frac{F_{i}-\min _{i}}{\max _{i}-\min _{i}}, \\
& I_{i}=\frac{\max _{i}-F_{i}}{\max _{i}-\min _{i}},
\end{aligned}
$$

where $I_{i}$ - index for a separate indicator (coefficient);

$\mathrm{F}_{\mathrm{i}}$ - actual value of an indicator (the coefficient);

$\min _{\mathrm{i}}$ - the minimum value of an indicator (coefficient);

$\max _{i}$ - the maximum value of an indicator (coefficient).

Based on the formulas $(1 ; 2)$, the indicators (coefficients) of various types of performance are reduced to relative levels (normalized before averaging), which leads them to a single measurement scale.

The principle of calculating each component of the consolidated efficiency index is to assess the relative distance between its actual value and the maximum (minimum). The result for each indicator will be expressed as a value from zero to one, and the closer to one, the higher the effect.

The second step is to compare social, economic, organizational and technological efficiency indices to determine which direction is more effective. If the social efficiency index is higher, then the activities of the cultural institution are aimed at the implementation of social projects, including those with a low economic effect; if the index of economic efficiency is higher, the organization pays more attention to the efficient use of resources, etc.

The third stage is the direct calculation of the consolidated efficiency index as a generalizing indicator using the average arithmetic indices of social, economic, organizational and technological efficiency, which will record the level of efficiency of a cultural institution within an industrial organization.

This indicator can be used by the stakeholders of the 3rd group to compare the activities of different cultural organizations, included and not included in industrial organizations, operating in different conditions and performing their tasks in different ways. 


\section{Conclusions}

In summary, it should be noted that corporate social responsibility and voluntary social reporting, ensuring the transparency of the company's activities through its wide public coverage, are one of the important prerequisites for the functioning and financing of the social sphere of an industrial enterprise in modern business conditions, which will help the enterprise to earn the image of a socially responsible subject and position itself as a party interested in the development of human capital.

Within the framework of this study, the following tasks were solved:

1. The directions for assessing the effectiveness and forecasting the activities of the social sphere of an industrial organization when compiling CSR have been developed, based on the concept of balanced scorecard and taking into account the effects typical for the social sphere.

2. A comprehensive system of balanced indicators has been developed for drawing up a social report, which allows assessing the effectiveness of the activities of cultural institutions that are on the balance sheet of industrial organizations, which takes into account the specifics and target priorities of their functioning, as well as the interests of all groups of stakeholders.

The new CSR compilation procedure associated with the integration of social reporting with the system of key performance indicators allows to monitor the performance of the social sphere by aggregated indicators within the framework of management by goals and is a powerful tool for strategic planning of the activities of cultural institutions.

\section{References}

Bainev, V. F. (2008). Novaya ekonomika: usloviya i aktual'nyye zadachi stanovleniya v stranakh byvshego SSSR. Novaya ekonomika, 9, 3-25. Retrieved from https://elib.bsu.by/handle/123456789/8552

Bowen, H. (1953). Social Responsibilities of the Businessman. N. Y.: Harper \& Row.

Caroll, A. (1999). Corporate Social Responsibility: Evolution of Definitional Construct. Business and Society, 38(3), 268-295. DOI: https://doi.org/10.1177/ 000765039903800303

Davis, K. (1960). Can Business Afford To Ignore Social Responsibilities? California Management Review, 2(3), 70-76. DOI: https://doi.org/10.2307/41166246

Fisyuk, T. T., \& Zakharova, E. Yu. (2017). Problema otsenki effektivnosti rezul'tatov deyatel'nosti uchrezhdeniy kul'tury v usloviyakh integratsii kul'turno-dosugovoy sfery $\mathrm{v}$ novyye obshchestvennyye otnosheniya i rynochnuyu ekonomiku. Uchenyye zapiski (Altayskaya gosudarstvennaya akademiya kul'tury i iskusstv), 3. Retrieved from 
Malei \& Afanasyeva, 2021. Business's Corporate Social Responsibility at the Post-Soviet Area: Features of Assessing the Effectiveness of an Industry Organization's Social Sphere

https://cyberleninka.ru/article/n/problema-otsenki-effektivnosti-rezultatov-deyatelnostiuchrezhdeniy-kultury-v-usloviyah-integratsii-kulturno-dosugovoy-sfery-v-novye

Freeman, R. (1994). E. The Politics of Stakeholder Theory: Some Future Directions. Business Ethics, 4(4), 409-421. DOI: https://doi.org/10.2307/3857340

Global Compact Network Belarus. (2020). [Data file]. Retrieved from http://globalcompact.by/globalcompactbelarus

Ivanova, E. A., Akopyan, A. R., \& Litovchenko, S. E. (2004). Korporativnyy sotsial'nyy otchet: kak pravil'no rasskazat' o vklade vashey kompanii $v$ razvitiye obshchestva. Prakticheskoye rukovodstvo. In: S. E. Litovchenko (Ed.). M.: Assoc. managers.

Kaplan, R. S., \& Norton, D. P. (2003). Organizatsiya, oriyentirovannaya na strategiyu. Per. s angl. Pavlova M. M.: ZAO «Olimp-Biznes».

Korsokova, M. I., \& Litovchenko, S. E. (2003). Corporate social responsibility: social expectations. Consumers, managers, opinion leaders and experts assess the social role of business in Russia. In: S. E. Litovchenko (Ed.). M.: Assoc. managers.

Kotler, P., \& Nancy, R. Lee (2007). Social Marketing: Influencing Behaviors for Good. L.A.: Sage Publications.

Krasnova, M. V. Sistema sbalansirovannykh pokazateley kak instrument podgotovki korporativnoy sotsial'noy otchetnosti, Mezhdunarodnyy bukhgalterskiy uchet, 2, 35-39. Retrieved from https://cyberleninka.ru/article/n/sistema-sbalansirovannyh-pokazateleykak-instrument-podgotovki-korporativnoy-sotsialnoy-otchetnosti/viewer

Levitt, T. (1958). The Dangers of Social Responsibility. Harvard Business Review, 36(5), 4150. Retrieved from http://57ef850e78feaed47e42-3eada556f2c82b951c467be415f62411. r9.cf2.rackcdn.com/Levitt-1958-TheDangersofSR.pdf

McGuire, J. (1963). Business and Society. N.Y.: McGraw-Hill.

Mukhamediyeva, S. A. (2011). Effektivnost' deyatel'nosti v sfere kul'tury. Vestnik Kemerovskogo gosudarstvennogo universiteta kul'tury i iskusstv, 14, 100-116. Retrieved from https://cyberleninka.ru/article/n/effektivnost-deyatelnosti-v-sfere-kultury

Post, J. E., Preston, L. E., \& Sachs S. (2002). Redefining the Corporation: Stakeholder Management and Organisational Wealth. Stanford: Stanford University Press.

Rutskiy, A. V. (2012). Ekonomika sfery uslug. In: A. V. Rutskiy (Ed.). Minsk: BGU.

Shvaiba, D. (2017). Economic Support Transformation Social Sector Industrial Enterprises in the Republic of Belarus: Theory, Methodology, Practice. Minsk: Intern. un-t "MITSO".

Steurer, R., Langer, M., Konrad, A., \& Martinuzzi, A. (2005). Corporations, Stakeholders and Sustainable Development I: A Theoretical Exploration of Business-Society Relations. Journal of Business Ethics, 61(3), 263-281. Retrieved from http://www.jstor.org/stable/25123621

Vasil'kova, I. V. (2008). Effektivnost' deyatel'nosti uchrezhdeniy kul'tury. Spravochnik rukovoditelya uchrezhdeniya kul'tury, 2, 8-16. Retrieved from http://fulltext.pl.spb.ru/ unor/metod/cpr_rkv08_3_8.pdf 